Cataloging and Classification Quarterly, 1997, vol. 24, no. 1, pp.23-33.

Print ISSN: 0163-9374, Online ISSN: 1544-4554

DOI: $10.1300 / J 104 v 24 n 01 \_03$

http://www.informaworld.com/smpp/title $\sim \mathrm{db}=$ all $\sim$ content $=\mathrm{t} 792303976 \sim \mathrm{db}=\mathrm{al}$

http://www.tandf.co.uk/journals/haworth-journals.asp

http://dx.doi.org/10.1300/J104v24n01_03

(C) 1997 by Haworth Press, All rights reserved.

\title{
Changes in Technical Services and Their Effect on the Role of Catalogers and Staff Education: An Overview
}

\author{
Magda El-Sherbini \\ George Klim
}

SUMMARY. Though all library operations are affected by the development of technology, technical services operations are the first to undergo massive organizational restructuring in response. Some current changes and their effects on library cataloging departments are addressed. Two cataloging options are discussed. One is the use of vendor services, such as OCLC's Contract Cataloging, Prompt-Cat, and OCLC Selection. The other is the use of non-traditional staff. The impact of such changes on the role of librarians and on staff education is considered.

\section{INTRODUCTION}

Libraries are dynamic organizations, always subject to the changes taking place in the fields of information and education. During the last decade, the revolution in information technology has played art enormous role in changing libraries. Although all library operations are affected by the development of technology, technical services operations seem to be the first to undergo massive organizational restructuring in response to the technological changes. In this paper, some of these changes and their effects on library cataloging departments are discussed. It also addresses some issues related to the effects of these changes on the education of cataloging personnel and the changing roles and responsibilities of technical services staff.

Gary M. Shirk articulates some of the changes that are having such a profound impact on libraries. He writes: "Technological trends in computerization, communications, database availability, and standards have created an environment of fast-paced change in the information industry. This turbulent environment, coupled with society's decreasing support of education, declining library budgets, the triumph of access over ownership, and the new faith in business solutions to governmental issues, are forcing radical change in the ways that libraries and their suppliers interrelate." ${ }^{1}$ Taking a bookseller's perspective allows Shirk to pinpoint precisely the very core of the changes affecting libraries.

In response to such powerful external factors impacting libraries in general and technical services in particular, the administrators of technical services departments are adjusting their view of technical services and how they manage technical services operations. In order to keep pace with the ever changing world of information, new and non-traditional methods of dealing with long standing problems are being introduced and libraries are beginning to examine the role 
played by librarians and technical staff in the technical services operations. New approaches and services help secure radical reduction of backlogs.

Historically some of the solutions to a library's internal problems came, somewhat unexpectedly, from outside sources. Grappling with shrinking budgets and internal organizational restructuring, libraries turned to vendor services to deal with the mounting processing and cataloging problems. Using vendor services such as the OCLC PromptCat, OCLC Selection (formerly PromptSelect), notification services, and repeat search in which searching for materials is done automatically, ${ }^{2}$ libraries began to address their processing problems, and to seek innovative solutions.

Until recently, academic libraries have tended to depend on professional catalogers with MLS degrees for both original cataloging and copy cataloging. There were some variations in this approach as some libraries used catalogers to perform original cataloging, assigning subject headings and call numbers, and to do authority work, while non-professional staff were used to do straight-forward copy cataloging. With the developing shift in library priorities, some of these divisions have ceased to exist and the task, of copy and even original cataloging is increasingly being assigned to technical staff. In turn, professional catalogers are being assigned the responsibility for education and training of staff, quality control of the product, and management of the new workflow.

In an effort to further streamline their operations, many libraries are combining similar operations to reduce repetition of work and to increase efficiency. For example, some academic libraries are combining copy cataloging operations with the acquisitions process, thus taking advantage of the capabilities of the newly developed integrated systems. These libraries are creating fast cataloging units to do the straight-forward copy cataloging at the point of material receipt. The development of OCLC's Passport for Windows has played a major role in making this innovation possible. Libraries are able to download bibliographic records directly from the OCLC database to their local systems at the time of ordering the title.

At this critical point in their development, libraries are faced with a number of options in dealing with materials processing. In addition to the traditional method of attempting to procure large grants for special cataloging projects, libraries seek more innovative ways of dealing with cataloging problems. In this paper two options are studied: vendor services, and using nontraditional staff to perform cataloging. The impact these changes have on the role of librarians and on staff education is also discussed.

\section{VENDOR SER VICES}

There are a number of vendors specialized in providing libraries with cataloging and related services. One such vendor is the Professional Media Services Corp., ${ }^{3}$ specializing in providing libraries with services related to audio-visual materials. The service includes any or all of the following: selection, collection development, acquisitions operations, the creation and transmission of original cataloging, physical item preparation and delivery. OCLC is another major vendor and its services include cataloging as well as acquisition, interlibrary loan, and collection development. ${ }^{2}$ OCLC's Contract Cataloging, PromptCat, and OCLC Selection will be discussed as examples of vendor services. 


\section{Contract Cataloging}

Faced with the need to provide access to semi-permanent backlogs and newly arriving materials, libraries turned to alternative cataloging methods. Outsourcing is one method which has been practiced for some time and appears to be gaining favor in many institutions. Studies on the subject have proven that it is a viable means of obtaining cataloging records for library materials, ${ }^{4}$ and that the cost of cataloging is lower than hiring staff in the library to do cataloging. ${ }^{5}$ Some libraries have performed their own cost studies to help decide whether to outsource or to catalog in-house. ${ }^{4}$

Individual library needs determine the extent to which materials are outsourced. On the one extreme, entire library cataloging departments are closed and all materials are outsourced, as in the case of Wright State University. ${ }^{5}$ However, it is more common to outsource parts of collections. Foreign language collections, which are frequently difficult to deal with, are often targeted for this purpose. Some libraries have decided to contract out original cataloging only, while continuing to perform copy cataloging in-house.

Existing literature on the subject allows the librarian to make educated decisions in selecting vendors and deciding on the level of service desired. In a typical situation, partial outsourcing is chosen as a solution to the local problem. Colleen Hyslop states that "I believe that the more prevalent model, particularly for large research libraries, will be to utilize outsourcing as one of several tools. I view outsourcing not as a threat but as a valuable service which enhances our internal operations." 6 Outsourcing becomes one of the many methods available to the library manager for dealing with cataloging problems.

Gary Shirk ${ }^{1}$ also raises the important issue of integrating contract cataloging into the library's plan for dealing with cataloging issues in general. He mentions that "When outsourcing is the result of a strategic assessment of the organization's functions, employees gain a clearer picture of the organization's goals." He also states that "library leaders do not need to raze the existing organization and rebuild from the ground up to use outsourcing effectively. They need to focus first on the library's central strategy; outsourcing will have positive results if the library can concentrate on the key functions that contribute most to achieving its goals, lowering costs, gaining technological advantages benefiting from specialized expertise, increasing their ability to respond flexibly to need, and allowing them to use their staff in the most appropriate way."

From these two examples, outsourcing emerges as an extension to library technical services operations. It assists library staff in processing more materials and in making even those 'difficult to manage' materials available to patrons.

The quality of records obtained from the contractor depends as much on the contractor's ability to produce quality records as it does on the success of the librarian in explaining the needs of the library, educating the contractor staff, and fine-tuning the process. Quality control is crucial in this process. Library catalogers must make sure that the quality of records is uniformly maintained, and where necessary determine the possible causes of problems, communicate them to the contractor, and follow up with written instructions or actual training sessions.

Since a growing number of libraries are either participating in some contracting scheme or are considering one, it may be useful to analyze some of the benefits and dangers of outsourcing.

On the positive side, one could mention the following:

1. The library does not have to deal with a complicated workflow and the question of 
who does what.

2. The library keeps current with its new acquisitions regardless of the number of volumes acquired. It is the vendor that must find appropriate personnel to deal with cataloging and to meet the deadlines.

3. The library does not have to deal with staff hiring, job description, evaluation, and solving conflicts between staff and department.

4. There is a decrease in the problem of not having book on the shelves, with consequent frustration of public services staff and patrons.

5. There is a saving on equipment, retirement, sick leaves, vacations, etc.

6. There is a saving of working space.

On the down side, there are some problems with contract cataloging:

1. The vendor catalogs according to written specifications. If the library is not articulating its requirements clearly, it might get a different quality than expected.

2. Clear specifications are not enough. The library must also do regular spot checking to check the quality of the cataloging. The vendor will often recruit new staff or move existing staff to other assignments. The new cataloger will have to learn the library specification, and meantime may produce non-standard work.

3. Through contracting out library materials work, the library loses its professional catalogers.

4. Cataloging standards are going down. The library's written cataloging specifications will result in charges for every bit of work done. Every additional access point, for example, will cost the library extra money, and so some libraries are simplifying/reducing their standards. For example, instead of specifying a requirement for full analysis of a book which would result in assigning several subject headings, they specify only one broad subject heading. This constraint has a serious negative impact on retrieval and access to materials.

5. When cataloging was done in-house, if public services staff or patrons found a problem with cataloging, the cataloger would make the corrections. Thus, if the class was wrong, or the subject heading was not accurate, or the heading was not established according to the rules, the catalog would be amended. With contract cataloging, changes are often not made so that public services staff and patrons have to live with the problems.

In conclusion, it is useful to point out that outsourcing seems to function well when it is planned carefully and becomes part of an overall scheme to deal with complex cataloging problems. It has been used to replace all of the cataloging operations in some cases, but the impact of such a decision is yet to be determined.

\section{PromptCat}

PromptCat is a product that sets a library's holding symbol on the OCLC file at the time the library receives a title on its approval plan. This OCLC service ${ }^{7}$ automatically provides copy cataloging for monographic materials supplied by participating book vendors. Vendors currently 
active include Academic Book Center, Yankee Book Peddler, and Blackwell North America. Vendors about to become active are Ambassador Book Service, Eastern Book Company, Puvill Libros, and Majors Scientific Books, while agreements have been reached with Baker \& Taylor Books and with Broader Books \& Services.

PromptCat "is a good compromise position between totally outsourcing a workflow that represents a high volume of material and full-in-house processing." 8 Granskog also says that "by elimination of OCLC search and update costs and implementing a check-in-on receipt approach for many materials, they can free their higher level cataloger staff to tackle non-book formats, original cataloging, assigning and updating records." 8

\section{OCLC Selection}

OCLC Selection is another service provided by OCLC, ${ }^{9}$ which automates materials selection and ordering procedures. Through this new service libraries will be able to search Bowker's Book in Print (BIP) and OCLC's Online Union Catalog, thus achieving a great saving in staff time.

There is no doubt that service providers such as OCLC will have a great impact on library staff and libraries. They allow library managers to restructure library departments and utilize better the existing skills of the library staff. As libraries delegate the more routine processing to non-professional staff, student assistants, or to vendor services, its librarians are freed to catch up on the rapid development in technology and to devise ways to provide access to materials whether in printed formats or electronic formats. Professionals can thus use their skills and experience to develop library Internet sites, create home pages, make decisions on cataloging Internet resources and select what is to be cataloged.

\section{The Impact of Vendor Services on Library Personnel and Their Education}

As libraries prepare to deal with old technical problems by using new technologies and methods, a large share in this process is played by technical services librarians, who are often assigned responsibility for planning, implementing, managing, and evaluating the new services and procedures. This shift is frequently accompanied by some trepidation on the part of other librarians, who are now required to assume some of the cataloging functions reserved previously for the full-time professional cataloger. Barbara Winters states that "Some librarians have maintained that the long-term result of outsourcing cataloging work may be the elimination of a core of experts on cataloging." ${ }^{5}$ However, Winters believes that the "reverse will be true-that mundane cataloging will be relegated to outsourcing while professionals will be freed up to give descriptions of new electronic resources. ... They will also manage cataloging contracts and evaluate on an ongoing basis the quality of contractor-supplied records. As competition increases among cataloging contractors, as it will, cataloging experts will have to remain aware of the marketplace to determine whether newer alternatives are better for their local institution." 5

Further evidence of the debate surrounding the shifting of responsibilities in the cataloging departments is provided by Vicky Reich. She states that "the cataloger has a broad view of the systematization of knowledge. Their skills will continue to be needed for creation, building, and maintenance of knowledge navigation systems. Catalog staff should be working 
side by side with the computer staff, lending expertise to the organization of CWIS system, the integration of CWIS systems with the library's online catalogs, and even with design and implementation of Internet resources (for example the MOSAIC home page), creating hyperlinks among new materials." 10

Thus, in a typical model of an outsourcing operator, the librarians select and prepare materials, negotiate contracts, write specifications, set up delivery systems, oversee the operation, provide for quality control and monitor budgets and expenditures. This calls for the creation of teams, where a librarian would prepare the project, oversee the set-up, and manage the operation, but the actual day to day operation would be handled by non-professional staff.

In addition to managing the new processes and procedures, the librarian automatically assumes the role of an educator, as he or she prepares to train the staff for their new responsibilities in the department. The other side of the education formula consists of the role of educating the outside contractors in the local practices and requirements of the client library. This may involve elements ranging from drafting actual contract specifications, to explaining those specifications, to educating the contractor's staff and management. This last element is particularly important, as contractors frequently employ non-professional staff to do their cataloging, and the contracting library must therefore provide detailed specifications and education if it is to receive work of suitable quality from them.

\section{NON-TRADITIONAL STAFF USE}

The library profession draws a clear line between responsibilities assigned to the professional librarian, who hold an MLS degree, and to those assigned to non-professional staff. Further distinctions are sometimes made between the latter and part-time student assistants who are hired to support existing library operations. These distinctions are usually maintained and supported by Cataloging Departments in most libraries, often creating three levels of responsibility among the staff.

Distinction among the first two was drawn based on the cataloging record itself. Professional catalogers had the responsibility for creating original bibliographic records. Their education and experience guaranteed that standards were observed and that the best possible records were created. These bibliographic records contributed to the creation of local, national, and international catalogs.

In this scheme, non-professional staff were assigned the responsibility of copy cataloging, which consisted largely of using existing records to load into local systems. As the need arose, student assistants would be used to help locate and identify these records in existing catalogs and to perform some of the routine work associated with copy cataloging.

As the changes described previously began to impact on catalogers and their ability to maintain the quality and quantity of their work, the notion of using "non-traditional" staff to perform certain higher level cataloging duties hitherto reserved for the professional librarian was entertained. Within the scope of this argument, non-traditional staff could be defined as nonprofessional staff persons or student assistants who do not have a library degree and whose role in the Cataloging Department has generally been limited to lower level processing of library materials. Depending on the institution, this may have included searching the OCLC database or other bibliographic utilities for matching bibliographic records, and editing those records by adding or deleting data to fit the local online cataloging system. Roles in the department become 
"non-traditional" as staff assume responsibilities previously reserved for professional catalogers; these responsibilities include original cataloging.

Non-professional copy catalogers were first considered for this shift at the Ohio State University Libraries (OSUL). Copy cataloging staff there had extensive experience in high level copy cataloging, including problem-solving such as assigning call numbers based on LC subject headings, assigning call numbers for literary works, creating new records based on existing data such as new editions, and creating new records for literary works. Copy catalogers were also used to perform original cataloging when appropriate training was provided. As this shift in responsibilities occurred, the lines between cataloging functions became blurred and OSUL began to experiment with another option. Graduate Administrative Assistants were hired to assist the department in cataloging foreign language materials. These were graduate students at the university with native proficiency in Arabic, Hebrew, Persian, and Slavic languages. After extensive training in all phases of cataloging operations, these students were used for copy cataloging, and after more training and under the direction of professional librarians, they carried out original cataloging of materials in their languages.

This experiment has proven very successful:

1. high quality records were obtained

2. improved productivity, through good staff motivation

3. the elimination of old and complicated workflow procedures

4. streamlining of technical services operations and the creation of cataloging teams, with a professional librarian as team leader.

As the function of copy cataloging and original cataloging performed by original catalogers or by non-professionals or by student assistants overlapped, a successful integration of the new working model took place. Professional librarians assumed leadership roles as team leaders and project planners. Non-professional staff members began to perform original cataloging, and they assumed more supervisory roles in addition to their traditional duties. Infusion of new ideas and practices through the use of Graduate Administrative Assistants provided motivation for innovation and experimentation in other areas. The OSUL experience with the use of non-traditional staff, including Graduate Administrative Assistants, has produced very positive results thus far.

If the bulk of the copy cataloging is shifted to the student assistants, then what is left for copy catalogers to do? Copy catalogers are non-professional staff persons with cataloging experience. Their experience should be utilized differently by training them in performing original cataloging and problem-solving. Though it may be argued that copy catalogers are not familiar with the cataloging rules, nevertheless some libraries have already made this shift by redefining the copy cataloging function into two parts: (1) processing; (2) high level copy cataloging. Processing includes searching and finding a matching record and processing this record. This function in such libraries is done by student assistants. Copy catalogers can then do higher level work, and those who have lots of experience can be retrained to perform original cataloging, under the supervision of a professional. 


\section{CONCLUSION}

The role of the cataloging librarian is changing. Catalogers are becoming managers, teachers, and trainers of non-professionals. They manage outsourcing projects, provide quality control, and database management. Reich states that "the some of the cataloging skills now used by catalogers will continue to be used: broad discipline knowledge and the use of consistent rules for organizing information. Some new skills will be needed, such as the ability to scan materials online, the ability to break apart online materials into appropriate units for organization, and the ability to work more fluidly with different media as pointers and guides to information." 10 Catalog librarians are becoming more involved in technology, management, training, and education; their skills are no longer restricted to simply cataloging of materials.

In developing their curricula, library schools need to emphasize management of cataloging and how to train non-professionals to do cataloging, while at the same time continuing to teach the theory of cataloging and the rules. Library schools must now also relate their teaching of cataloging and classification to the emergent technology. This new approach will produce a generation of catalog librarians able to respond to the needs of today and tomorrow.

\section{REFERENCES}

1. Gary M. Shirk, "Outsourced Library Technical Services: The Bookseller's Perspective," Library Acquisitions 18 (Winter 1994): 383-95.

2. OCLC Home Page. <URL: http://www.oclc.org>

3. Linda F. Crismond, "Outsourcing from the A/V Vendor's Viewpoint: The Dynamics of a New Relationship," Library Acquisitions 18 (Winter 1994): 375-381.

4. Magda El-Sherbini, "Contract Cataloging: A Pilot Project for Outsourcing Slavic Books," Cataloging \& Classification Quarterly 20:3 (1995): 57-73.

5. Barbara A. Winters, "Catalog Outsourcing at Wright State University: Implications for Acquisitions Managers," Library Acquisitions 18 (Winter 1994): 367-373.

6. Colleen F. Hyslop, "The Future Is Now: The Changing Face of Technical Services," Remarks at the OCLCSponsored Symposium at the ALA Midwinter Conference in Los Angeles (Feb. 4 1994): 5.

7. Prompt Cat Home Page.

<URL: http://www.odc.org/oclc/promo/7771 prom/7771 ptct.htm>

8. Kay Granskog, "PromptCat Testing at Michigan State University," Library Acquisitions 18 (Winter 1994): 419-425.

9. OCLC Selection Home Page. <URL: http://www.oclc.org/oclc/promo/9255set9255.htm> 
10. Victoria Ann Reich, "A Future for Technical Services," Library Acquisitions 18 (Winter 1994): 359-361. 